The number of villi decreased in the upper region and was unchanged in the other regions, while villi height tended to be greater in the upper region and less in the other regions.

Total intestinal mucous surface expressed in terms of rat live weight, was not significantly reduced in the axenic subject.

\title{
ÉTUDE EXPÉRIMENTALE QUALITATIVE DE L'ABSORPTION INTESTINALE DES GLUCIDES APRËS INGESTION D'UN REPAS A BASE DE GLUCOSE OU D'AMIDON
}

\author{
A. AUMAITRE, A. RERAT*, P. VAISSADE* et P. VAUGELADE* \\ Station de Recherches sur l'Élevage des Porcs, \\ * Laboratoire de Physiologie de la Nutrition, \\ Centre national de Recherches zootechniques, I. N.R. A., \\ 78350 Jouy en Josas
}

L'absorption des glucides a été examinée de façon globale (NEWEY, 1967) au niveau de l'intestin grêle, au cours de la digestion d'un repas expérimental chez le porc éveillé, muni d'une double canule de la veine porte (ARSAC et RERAT, 1962) et de la veine jugulaire permettant un dosage en continu du taux de sucres réducteurs totaux pendant environ 8 heures (AUMAitre et al., 1969).

Les résultats de l'évolution de la glycémie pré et post prandiales peuvent être représentés graphiquement suivant l'animal, le jour ou le glucide considéré (RERAT et al., r973). Les variations individuelles instantanées de la glycémie sont bien connues et rendent difficile l'interprétation du phénomène de l'absorption. Cependant, en effectuant un certain nombre de répétitions, les valeurs moyennes de la glycémie porte et jugulaire peuvent être déterminées.

\section{I. - Méthodes d'interprétation}

Nous rapporterons deux séries d'observations, l'une sur 6 repas expérimentaux de $400 \mathrm{~g}$ de glucose, l'autre sur 9 repas à base d'amidon de maïs. L'estimation du nombre, de la durée et de l'intensité des pics de la glycémie (absorption) définis par une série de discontinuités dans le temps des valeurs maximum et minimum du taux sanguin des sucres réducteurs conduit à une courbe théorique. Par ailleurs, la courbe moyenne de la glycémie porte et jugulaire a été calculée à partir des valeurs obtenues toutes les 5 minutes pendant 8 heures.

\section{2. - Absorption des glucides après un repas à base de glucose}

L'élévation rapide et importante de la glycémie apparaît immédiatement après le début du repas. Les pics très marqués évoluent parallèlement sur les deux veines (fig. I). L'écart-type du temps aux minimum est en général faible (coefficient de variation de 3 à 12 p. Ioo) pour les deux veines. Par contre, la dispersion des valeurs de la glycémie aux minima et aux maxima est importante ; elle est cependant plus faible (c.v. de 9 à 36 p. roo) pour la veine porte, que pour la veine jugulaire (Ix à $46 \mathrm{p}$. IOo) dans le cas de la courbe théorique.

La courbe moyenne fait apparaître des minima et des maxima plus atténués mais à des temps 
semblables après le repas; la dispersion des valeurs moyennes de la glycémie, plus importante que dans la méthode précédente, en limite la signification ( 17 à $49 \mathrm{P}$. roo pour la veine porte, $2 \mathrm{I}$ à $57 \mathrm{P}$. Ioo pour la veine jugulaire).

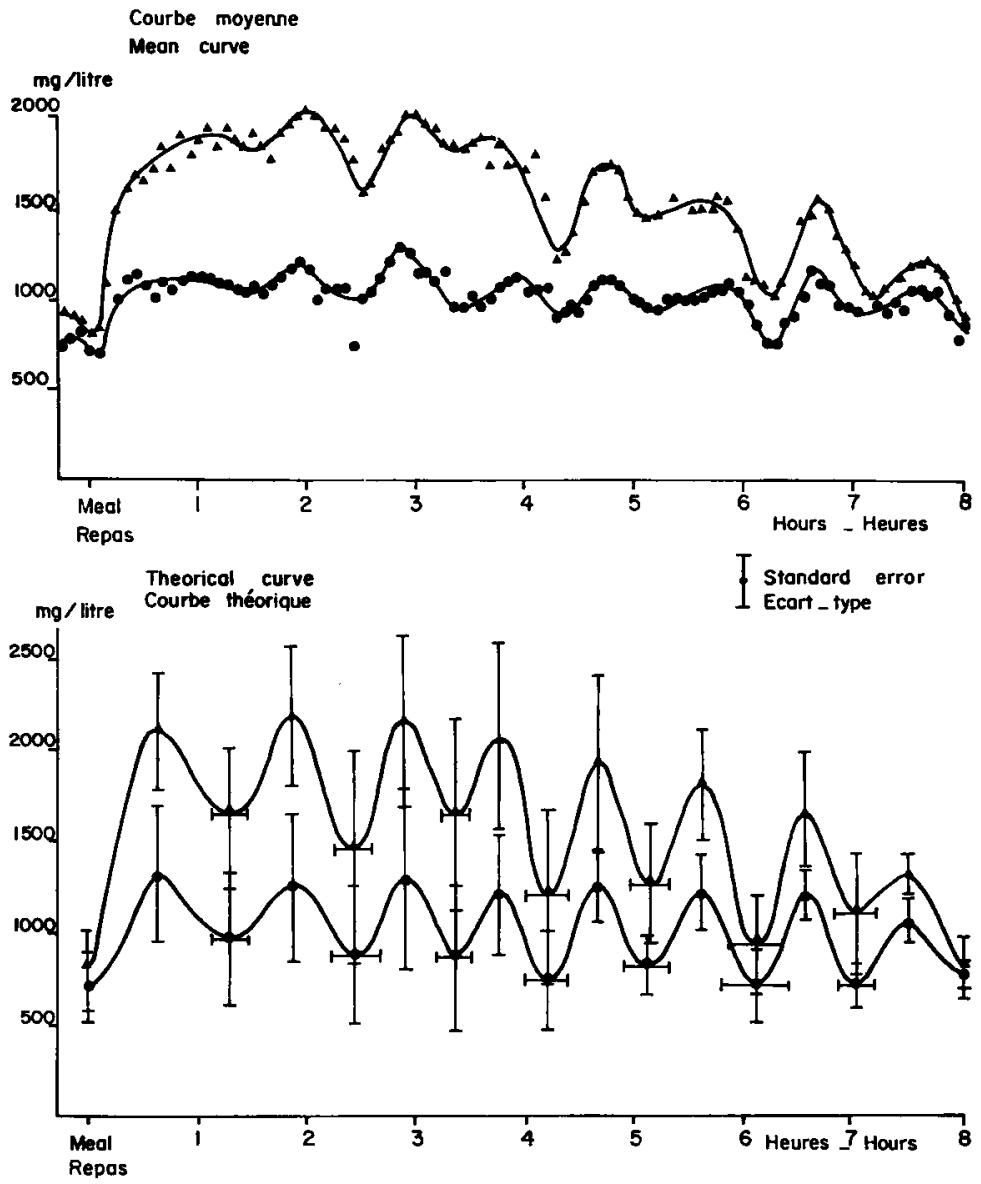

Fig. I. - Évolution de la glycémie pré- et post-prandiales après ingestion d'un repas à base de glucose : méthodes d'interprétation

FIG. 1. - Variations of the pre-and post-prandial glycemia after a glucose meal intake Methods of interpretation

- Veine porte. Portal vein

\section{3. - Repas à base d'amidon}

La glycémie post-prandiale présente une évolution semblable par la discontinuité de ses valeurs en fonction du temps (fig. 2). Cependant, les pics sont moins nombreux, plus atténués et leur durée est voisine des valeurs précédentes et peu dispersée (c.v. $=2$ à $7 \mathrm{p}$. I00). La glycémie aux maxima et aux minima varie moins que précédemment : 9 à 23 p. Ioo de c.v. pour la veine porte, 9 à 18 p. Ioo pour la veine jugulaire et la courbe théorique donne des valeurs plus précises que la courbe moyenne. L'augmentation de la quantité d'amidon ingérée (800 $\mathrm{g}-\mathrm{I} 200 \mathrm{~g}$ ) entraîne une augmentation parallèle de la glycémie du sang porte et périphérique (fig. 3) mais la discontinuité du phénomène est conservée à l'exception du cas de l'ingestion maximum (30 $\mathrm{g}$ de 

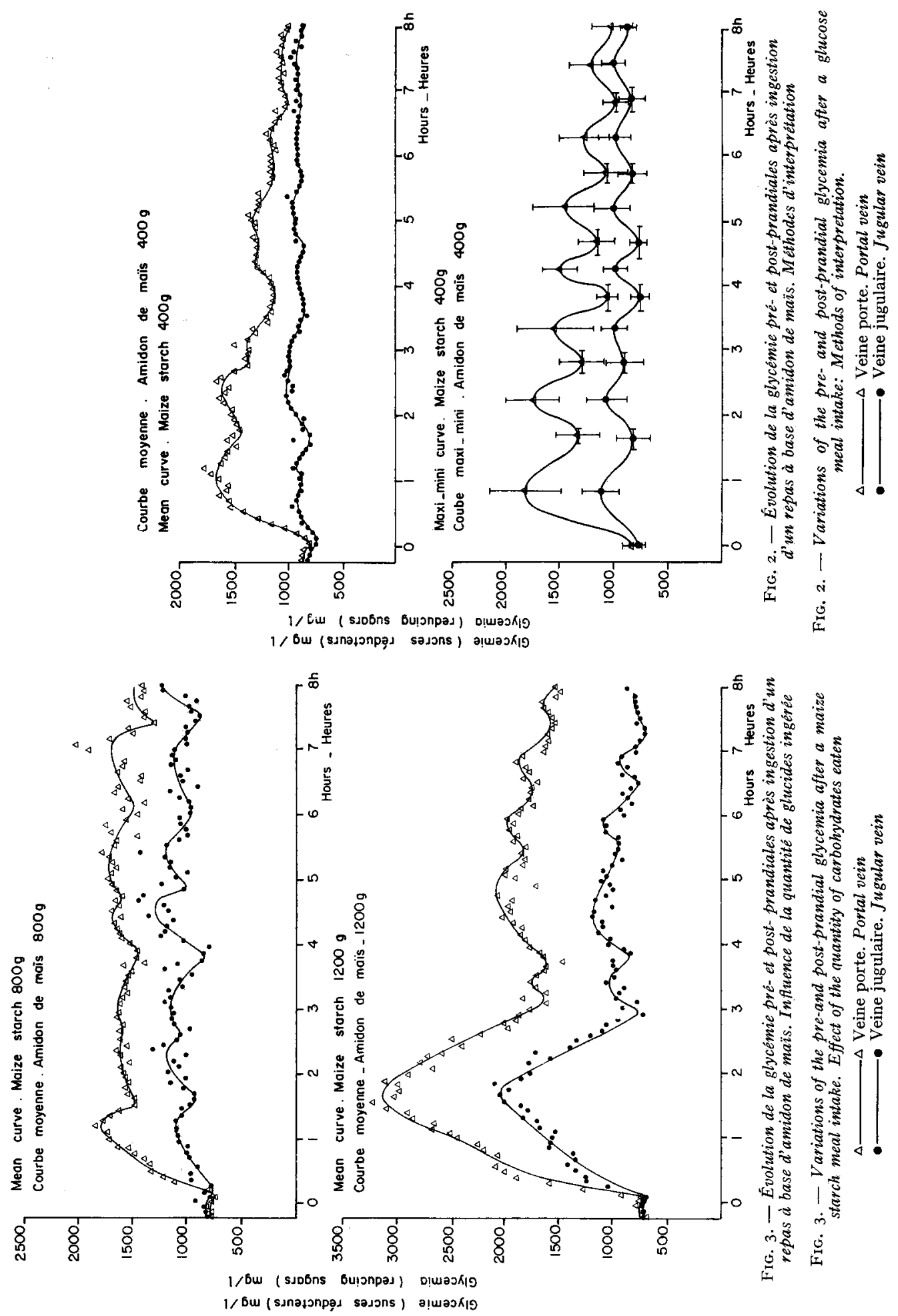
glucides/kg de poids vif) où les deux premiers pics sont confondus en un seul. Contrairement au phénomène observé pour le glucose et dans le cas de l'ingestion d'une quantité croissante d'amidon, la glycémie porte, qui après 8 heures n'est pas revenue au taux observé à jeun, semble indiquer que la digestion du repas se poursuit au-delà de cette durée.

La quantité de glucides absorbée est proportionnelle à la différence instantanée entre la glycémie des deux veines et à la différence des intégrales des deux courbes. On peut souligner que la courbe moyenne sous estimerait cette absorption (ro p. Ioo en moins) et donnerait une valeur moins précise en raison de la plus grande variabilité que la courbe théorique, surtout dans le cas des glucides à faible poids moléculaire comme le glucose.

\section{RÉFÉRENCES BIBLIOGRAPHIQUES}

(I) Newey H., 1967. Brit. Med. Bull., 23, 236.

(2) Arsac M., Rerat A., I962. Ann. Biol. anim. Bioch. Biophys., 2, 335.

(3) Aumaitre A., Fevrier C., Rerat A., Rigaud P., Thivend P., 1969. C. R. Acad. Sci., 268, $7 x 7$.

(4) Rerat A., Fevrier C., Aumaitre A., Vaissade P., Vaugelade P., ig73. Cah. Nutr. Diet., 8, I $54-156$.

\section{SUMMARY}

QUALITATIVE, EXPERIMENTAL, STUDY

OF THE INTESTINAI, ABSORPTION

OF CARBOHYDRATES AFTER A GLUCOSE OR STARCH MEAI, INTAKE

A general observation of carbohydrate absorption has been made in the small intestine (NEWEY, 1967), during digestion of an experimental meal in the conscious pig, fitted with portal and jugular vein fistulae, in order to realize a permanent determination of the total reducing sugars for about 8 hours (Aumaitre et al., r969).

The results of the variation in pre and post-prandial glycemia according to the animal, the day or the studied carbohydrate can be graphically shown (RERAT et al., 1973). The instantaneous individual variations in glycemia are well known and therefore the interpretation of the absorption phenomenon is quite difficult. However, thanks to a certain number of replications, the mean values of the portal and jugular glycemia can be determined.

\section{I. - Methods of interpretation}

We shall report two series of observations, the first one on 6 experimental glucose meals ( $400 \mathrm{~g})$, the second one on 9 maize starch meals. Estimation of the number, length and intensity of glycemia peaks (absorption) that are shown by a series of time depending discontinuities in maxima and minima values of the blood level of reducing sugars, leads to a theorical curve. On the other hand, the mean portal and jugular glycemia curve has been determined from values obtained every 5 minutes over an 8 hours period.

\section{2. - Absorption of carbohydrates after a glucose meal}

The rapid and large increase in glycemia appeared immediately after beginning of the meal. The well marked peaks varied in a parallel way in both veins (fig. I). Time standard-error for minima was generally low in both veins (variation coefficient between 3 and I 2 p. IOo). On the 
other hand, the dispersion of the glycemia values for maxima and minima was wide ; it was however lower (v.c. from 9 up to $3^{6} \mathrm{p}$. Ioo) in the portal than in the jugular vein (I I up to $4^{6} \mathrm{p}$. roo) as for the theorical curve.

The mean curve showed some more reduced minima and maxima but at similar times after the meal ; the signification of such an observation was limited by the dispersion of mean glycemia values, that was larger than with the previous method ( 17 up to $49 \mathrm{p}$. roo in portal vein, 2 I up to $57 \mathrm{p}$. roo in jugular vein).

\title{
3. - Starch meal
}

The post-prandial glycemia showed a similar variation because of the discontinuity of its values depending on time. However, peaks were less numerous, more reduced and their duration was close to the previous one and only slightly dispersed (v.c. 2 to $7 \mathrm{p}$. I0o).

Maxima and minima glycemiae varied less than before : 9 up to $23 \mathrm{p}$. roo (variation coefficient) in portal vein, 9 up to $18 \mathrm{p}$. Ioo in jugular vein and the values obtained with the theorical curve were more accurate than those of the mean curve. The increase in the starch intake (800-I $200 \mathrm{~g}$ ) led to a parallel increase in portal and peripheric blood glycemia, but the discontinuity of the phenomenon was maintained, however not in case of a maximum intake ( $30 \mathrm{~g}$ carbohydrates $/ \mathrm{kg}$, body weight) where the two peaks were identical.

Contrary to the observed phenomenon with glucose and in the case of increasing starch intake, portal glycemia, after 8 hours, was not back to the level observed in fasting animals, a fact which seems to indicate that the digestion of the meal is going on after that time.

The absorbed quantity of carbohydrates was proportional to the difference between the glycemia of both veins and to the difference between the integrals of both curves. It can be emphasized that the mean curve would underestimate that absorption (Io p. Ioo less) and would give a less accurate value because of the greater variability than the theorical curve and especially in case of carbohydrates with small molecular weight like glucose.

\section{MESURE QUANTITATIVE DE L'ABSORPTION DES ACIDES AMINÉS CHEZ LE PORC RECEVANT DES RÉGIMES A TAUX VARIABLES DE PROTÉINES}

\author{
A. RÉRAT et P.-H. DUÉE \\ Laboratoire de Physiologie de la Nutrition, \\ Station de Recherches sur l'Élevage des Porcs, \\ Centre national de Recherches zootechniques, I. N.R. A., \\ 78350 Jouy en Josas
}

Les bases d'une méthode permettant de mesurer les quantités de principes alimentaires absorbées par le tube digestif ont été exposées antérieurement (RéRAT, I97 I). Il s'agit, en l'occurrence, d'établir à tout moment après un repas défini, les différences de concentration de ces principes entre le sang efférent et le sang afférent de l'organe et de multiplier ces différences par le débit de sang correspondant. Dans ce but, des techniques indolores de prélèvement de sang ont été mises au point : canulation permanente de la veine porte permettant d'obtenir du sang efférent du tube digestif (ARSAC et RERAT, I962), canulation permanente de la veine jugulaire fournissant du sang 